\title{
KONSEP AL-QUR'AN DALAM PENERIMAAN HIDAYAH TENTANG PERBUATAN MANUSIA
}

\author{
Mohd Kailani \\ Fakultas Ushuluddin dan Studi Agama, UIN Sulthan Thaha Saifuddin, Jambi, Indonesia \\ Mohdkailani@uinjambi.ac.id
}

\begin{abstract}
Abstrak:
Penelitian ini terfokus pada pembahasan hidayah dalam al-Qur'an mengenai hubungan antara hak mutlak Allah dan perbuatan manusia, hidayah di fahami dalam persepsi yang berbeda beda baik tentang esensi maupun cara memperolehnya. Dalam penelitian ini memfokuskan pada apakah makna hidayah menurut al-Qur'an dan apakah hidayah merupakan hak prerogatif Tuhan ataukah ikhtiar hamba-Nya. Dalam penelitian ini untuk mengetahui konsep hidayah dalam al-Qur'an. Secara Mendalam tujuan nya yaitu ingin mengetahui bagaimana hakikat hidayah dan bagaimana sikap seorang untuk mendapat hidayah. Metode yang digunakan dalam penelitian ini adalah pendekatan tafsir metode maudhu'i sesuai dengan sipat pembahasannya. Penelitian ini mengungkap bahwa hidayah sebagai perangkat yang dimanfaatkan manusia untuk mendapatkan keselamatan dan kebahagiaan dan juga hidayah didapatkan oleh siapapun yang berusaha dan mempersiapkan diri untuk mendapatkannya, ia tidak didapat oleh orang yang tidak mempersiapkan diri.
\end{abstract}

Kata Kunci: Hidayah, Perbuatan, Manusia

\begin{abstract}
:
This research focuses on the discussion of guidance in the Qur'an regarding the relationship between the absolute rights of God and human actions, hidayah understood in different perceptions both about the essence and how to obtain it. In this study focuses on whether the meaning of guidance according to the Qur'an and whether hidayah is the prerogative of God or the efforts of His servants. In this study to find out the concept of guidance in the Qur'an. In depth, the goal is to find out how the nature of guidance and how the attitude of a person to get guidance. The method used in this study is the interpretation approach maudhu method; ' $i$ in accordance with the nature of the discussion. This research reveals that guidance as a tool used by humans to get safety and happiness and also guidance obtained by anyone who tries and prepares to get it, he is not obtained by people who do not prepare themselves.
\end{abstract}

Keywords: Hidayah, Action, Humans

\section{PENDAHULUAN}

Hidayah merupakan istilah yang populer yang sering kita dengar, bahkan telah membudaya dikalangan komunitas muslim di Indonesia, 
pengungkapan hidayah tidak lagi berkutat dalam bahasa ceramah mubaligh, khotbah dan dalam ritual kegamaan lainnya, akan tetapi ungkapan hidayah telah menjamah ruang gosip media massa, hal ini terlihat dari maraknuya tayangan sinetron yang "mengekploitas" hidayah dengan judul dan kisah yang beragam. Hidayah dalam bahasa media massa seakan hanya memvisualkan perubahan sikap seseorang kepada hal yang lebih baik setelah mendapatkan hukuman atas segala dosa yang pernah dilakukan.

Jika menuruti asumsi ungkapan diatas, paradigma hidayah mengerucut kepada pengertian yang parsial, yaitu terbatas pada perubahan sikap negatif menuju sikap positif, sehingga sering terdengar dalam komunitas masyarakat awam berbagai ungkapan tentang hidayah seperti “ saya belum memakai jilbab, karena belum mendapatkan hidayah" atau ungkapan dalam doa sehari-hari "ya Allah berikan kami taufiq dan hidayah". Dari kesan semua ungkapan tadi, timbul keinginan untuk menyelami apakah hidayah itu sesungguhnya.

Dalam cara memperoleh hidayah setidaknya ada dua persepsi masyarakat, Pertama yang berasumsi bahwa hidayah sebagai suatu yang positif dan petunjuk menuju perubahan lebih baik dari sebelumnya, sedangkan sikap dan perilaku yang negatif tidak termasuk ruang hidayah. Proses mendapatkan hidayah sangat tergantung pada keaktifan dan keinginan manusia itu sendiri untuk berubah, sedangkan Allah SWT. Hanya bersikap "Pasif". Kedua mereka yang berasumsi bahwa hidayah merupakan hal yang tidak bersinggungan dengan keinginan, harapan dan usaha manusia yang mendambakannya. Ia semata-mata kehendak mutlak Tuhan yang tidak semua orang mempunyai kesempatan yang sama untuk memperolehnya. Dari penjelasan ini dipahami bahwa hidayah semata-mata merupakan hak prerogatif Tuhan.

Corak pemahaman yang menegaskan bahwa hidayah sepenuhnya berada dalam ruang hak prerogatif Tuhan seringkali berargumentasi dari nash-nash kitab suci, diantaranya seperti yang termaktub dalam surah yunus ayat 99:

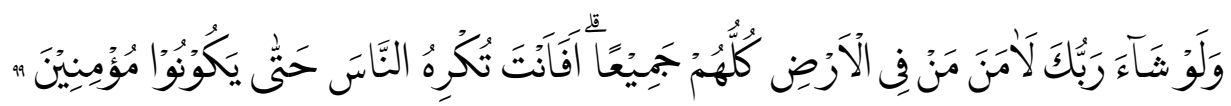

Dan jika Tuhanmu menghendaki, tentulah beriman semua orang di bumi seluruhnya. Tetapi apakah kamu (hendak) memaksa manusia agar mereka menjadi orang-orang yang beriman?

Ayat diatas diposisikan sebagai argumentasi atas interpretasi perolehan hidayah yang semata berorientasi pada "kehendak" Tuhan. Abd. Al-rauf ibn Ali Al-fansuri seorang ulama Indonesia yang berpandangan 
demikian. Dalam menerjemahkan surah yunus ayat 99 diatas ia mengatakan "dan jikalau dikehendaki oleh Tuhanmu ya Muhammad niscaya percaya orang yang didalam bumi sekalian mereka berhimpun. (Ridwan \& dkk, 2001, hlm. 58).

Maka engkaukah dapat menggagahi segala manusia dengan yang tiada dikehendaki oleh Allah ta'ala daripada mereka itu hingga adalah mereka itu mu;min tiada engkau dapat pada yang demikian itu. (al-Fansuri, t.t., hlm. 23)

Argumentasi ini berlandaskan kepada bentuk konkrit hidayah yang berupa agama dan iman. Keduanya-agama dan iman merupakan zona eksklusif dalam tutorial wewenang Tuhan yang absolut kepada segenap hambanya. Akhirnya pemahaman hidayah hanya berkonotasi positif dalam paradigma masyarakat awam, namun pada sisi lain, ada juga anggapan yang sangat kontras dengan pemahaman seakan baku yaitu yang berpandangan bahwa hidayah itu merupakan anugrah Tuhan yang diberikan kebebasan memilih bagi hambanya.

Pada posisi ini, hidayah menjadi hak pilihan hambanya, sedangkan Tuhan hanya sebatas merestui dengan segala konsekuensi yang telah ditetapkan. Pandangan semacam ini, antara lain, disampaikan oleh mufassir kontemporer al-Maraghi. Ketika menafsirkan surah yunus 99 diatas, ia mengatakan: kalau Tuhan engkau menghendaki untuk tidak menciptakan manusia dengan fitrahnya siap memilih yang baik dan buruk, iman dan kufur, atau menetapkan pilihan terhadap salah satu pilihan yang mungkin tentu Tuhan telah melakukan itu. Maka sesungguhnya ini (memaksa orang beriman) adalah diluar kemampuanmu dan bukan termasuk tugas risalahmu". (al-Maraghi, 2001, hlm. 188)

Kerangka realitas pemahaman hidayah yang bertentangan dalam persepsi ulama dan masyarakat awam diatas, menandakan ada persoalan dalam memahami masalah hidayah. Oleh sebab itu, harus segera mendapatkan pencerahan agar duduk perkara hidayah sesuai dengan esensi dan posisi dengan semestinya, mengingat hal ini akan memberikan pengaruh yang cukup besar dalam kehidupan keberagamaan masyarakat.

Jika mengikuti pola logis pandangan pertama, maka nilai keberagamaan seseorang menjadi stagnan (jumud), karena hidayah hanya sebatas anugrah dan taqdir dari Tuhan. (Sabiq, 1992, hlm. 95).

Bagi yang memperoleh hidayah berarti baginya rahmat Tuhan, namun bagi yang tidak, berarti Tuhan masih menyayanginya dengan selalu mencoba keimanannya. Jika mengikuti logika pandangan kedua, nilai keberagamaan seseorang menjadi dinamis. Ia akan terus menerus mencari hidayah Tuhan dalam upaya untuk menuju kesempurnaan dalam beragama. Selama ini 
justru yang berkembang di masyarakat corak pandang yang pertama, bahkan dalam rangka untuk membenarkan pandangan-pandangan itu, ayat-ayat hidayah dalam al-Qur'an sering di eksploitasi sesuai pola pikir masingmasing kelompok. Pertanyaan kemudian adalah, apakah hidayah seperti pandangan masyarakat yang dominan itu? atas dasar inilah Pengkajian cara mendapatkan dalam al-Qur'an mendesak untuk dilakukan.

Pengkajian terhadap hidayah dalam -al-Qur'an semakin urgen jika dihubungkan dengan perkembangan dinamika sosial masyarakat Islam dewasa ini. Mengingat dinamika sosial yang selalu eskalatif seiring dengan pesatnya perkembangan sains dan teknologi, maka pemahaman yang baik dan benar terhadap hidayah penting untuk dikemukakan hal ini karena ada hubungan dengan sikap keberagamaan seseorang.

Dalam menghadapi perubahan itu, ketahanan mental beragama menjadi suatu yang sangat penting untuk diperhatikan. Tanpa ketahanan mental beragama, maka masyarakat Islam akan tergilas oleh arus globalisasi yang selamanya tidak positif, bahkan terkadang negatif, dalam upaya untuk membangun ketahanan mental beragama itu, maka keberagamaan masyarakat Islam harus bersifat Dinamis, dan dinamika keberagamaan masyarakat Islam, antara lain ikut di-pengaruhi oleh pandangannya mengenai hidayah Tuhan dalam kehidupan beragamanya.

\section{PEMBAHASAN}

\section{Pengetian Hidayah}

Kata Hidayah berasal dari bahasa Arab merupakan dari kata al-Hadyu, Al-Irsyad, al-Taujih (Munir, 1985). Namun dalam bahasa Indonesi, kata Hidayah berarti petunjuk dari Tuhan.(Salim \& Salim, 1991, hlm. 523).

Dalam al-Munjid disebutkan bahwa kata (هدى dan هداية ) adalah dua kata dari bentuk masdar kata (hadaya), dua masdar lainnya adalah hadyan dan Hidayatan. Kata Hidayah digunakan dalam pengertian yang lebih cenderung bersifat aktif (bermakna aktifitas) sehingga lebih tepat jika diterjemahkan dengan memberi petunjuk, membimbing atau menuntun, sebaliknya kata hudan digunakan dalam pengertian bersifat pasif (keadaan) sehingga lebih tepat jika diterjemahkan dengan buku petunjuk, buku pedoman, dan buku bimbingan yang memerlukan peran aktif manusia untuk memahaminya.(Ma'luf, 1986, hlm. 859). Oleh karena itu didalam al-Qur'an kata huda dilawankan bukan dengan kata idhlal (penyesatan) tetapi dengan kata dhalalah (kesesatan) sebagaimana firman Allah SWT dalam surah alBaqarah ayat 16 :

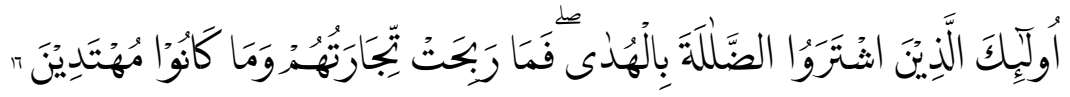




\section{AT-TIBYAN}

Journal Of Qur'an and Hadis Studies

Volume. 2 No. 1 (Juni 2019)

Mereka itulah yang membeli kesesatan dengan petunjuk. Maka perdagangan mereka itu tidak beruntung dan mereka tidak mendapat petunjuk.

Sedangkan kata Hidayah dalam berbagai tulisan keagamaan selalu dilawankan dengan kata idhlal bukan dhalalah (Sabiq, 1992, hlm. 106).

Kata lain yang memiliki akar yang sama dengan huda adalah al-hadi yang merupakan bagian dari nama Allah (asma al-husna). Menurut ibn Atsir al-Hadi adalah yang memperlihatkan dan memperkenalkan kepada hambanya jalan mengenalnya. Sehingga mereka mengikrarkan keTuhanannya Allah yang menunjukkan segenap makhluk kepada sesuatu yang harus (ibn Asyir, t.t., hlm. 167).

Dari berbagai pengertian diatas dapat disimpulkan bahwa ada perbedaan penggunaan antara kata hidayah dan kata hudan. Kata hidayah cenderung bersipat aktif, membutuhkan suatu aksi, sementara kata hudan bersipat menunjukkan makna pasif (keadaan). Kemudian kata hidayah berkonotasi kepada perubahan positif. Sedangkan kata hudan lebih cendrung kepada konten dari pentunjuk itu sendiri.

\section{Pandangan Ulama Tentang Hidayah}

Para ulama menggunakan istilah yang berbeda dalam menguraikan hidayah perbedaan uraian tersebut dapat dilihat dari pandangan mereka tentang tingkatan hidayah.

Al-Baidawi memandang bahwa hidayah itu banyak jenisnya yang dapat disimpulkan dalam empat kelompok besar (Baidhawi, t.t., hlm. 35) yaitu:

1. Memberikan kemampuan kepada seseorang sehingga dengan kemampuan itu ia dapat menangkap petunjuk menuju hal-hal yang baik bagi dirinya, seperti kemampuan berpikir.

2. Membuat rambu-rambu yang membedakan antara yang benar dan yang salah, antara baik dan buruk. Rujukan adalah Firman Allah SWT surah al-Fushshilat ayat 17 dan al-Balad ayat 10 :

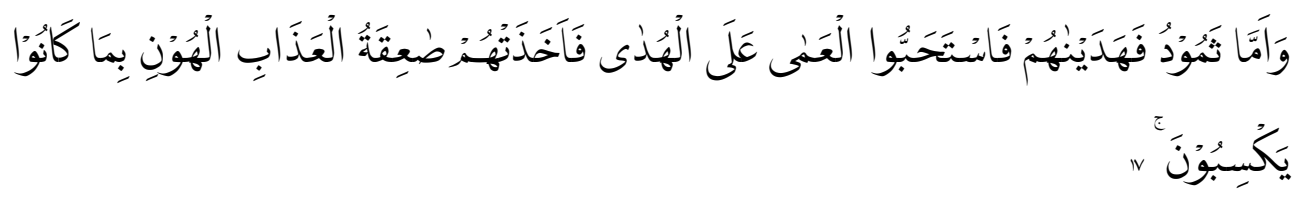

Dan adapun kaum Samud, mereka telah Kami beri petunjuk tetapi mereka lebih menyukai kebutaan (kesesatan) daripada petunjuk itu, maka mereka disambar petir sebagai azab yang menghinakan disebabkan apa yang telah mereka kerjakan.

Dan : 


\section{AT-TIBYAN}

Journal Of Qur'an and Hadis Studies

Volume. 2 No. 1 (Juni 2019)

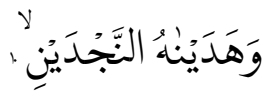

Dan Kami telah menunjukkan kepadanya dua jalan (kebajikan dan kejahatan),

3. Mengirim para rasul, menurunkan kitab suci, dasarnya adalah firman Allah SWT. Al-Isra' ayat 9 dan al-Anbiya ayat 73:

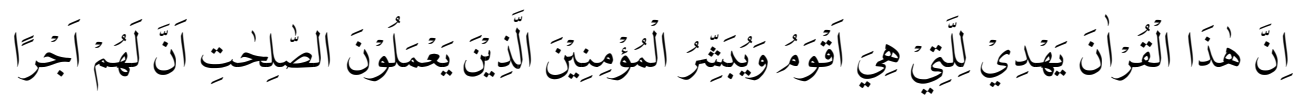

Sungguh, Al-Qur'an ini memberi petunjuk ke (jalan) yang paling lurus dan memberi kabar gembira kepada orang mukmin yang mengerjakan kebajikan, bahwa mereka akan mendapat pahala yang besar,

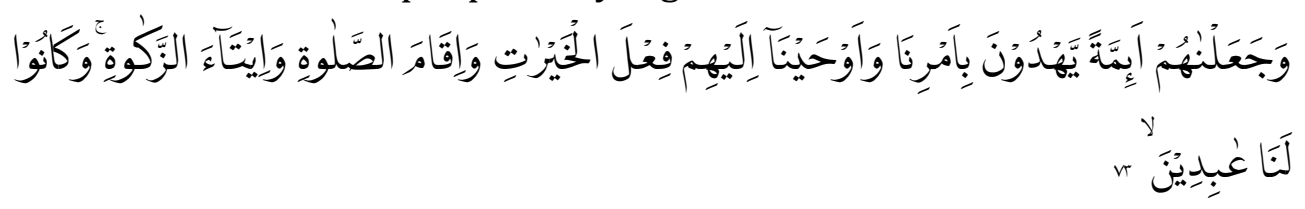

Dan Kami menjadikan mereka itu sebagai pemimpin-pemimpin yang memberi petunjuk dengan perintah Kami dan Kami wahyukan kepada mereka agar berbuat kebaikan, melaksanakan salat dan menunaikan zakat, dan hanya kepada Kami mereka menyembah.

4. Membukakan rahasia-rahasia kepada hati manusia dan menampakkan berbagai hal kepada mereka, sebagaimana wahyu, ilham dan mimpi dalam tidur"(Baidhawi, t.t., hlm. 987). Dan ini merupakan hidayah khusus yang diberikan kepada para Nabi. Dasarnya firman Allah SWT surah al-An'am ayat 90 dan al-Ankabut ayat 69.

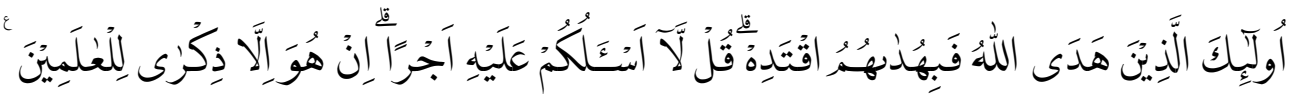

Mereka itulah (para nabi) yang telah diberi petunjuk oleh Allah, maka ikutilah petunjuk mereka. Katakanlah (Muhammad), "Aku tidak meminta imbalan kepadamu dalam menyampaikan (Al-Qur'an)." Al-Qur'an itu tidak lain hanyalah peringatan untuk (segala umat) seluruh alam.

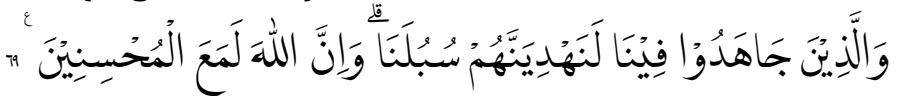

Dan orang-orang yang berjihad untuk (mencari keridaan) Kami, Kami akan tunjukkan kepada mereka jalan-jalan Kami. Dan sungguh, Allah beserta orang-orang yang berbuat baik.

Muhammad Abduh sebagaimana dikemukakan Rasyid Ridah, membagi hidayah pada lima tingkatan, yaitu : 
1. Hidayah Naluri Hidayah ini dinamakan juga dengan Hidayah alWujdan al-Thabi'i, Menurutnya Hidayah ini sudah diberikan kapada bayi semenjakl ia dil;ahirkan. Pandangan in berpendapat dengan rasa tidak nyaman ketika tubuh si bayi memerlukan gizi, yang terekpresikan dalam jerit tangisan ketika meminta diberikan makana. Hidayah inilah yang mendorong anak tersebut mengisap-isap puting ibunya ketika dimasukkan kedalam mulutnya (Rasiyd Ridho, t.t., hlm. 57).

2. Hidayah inderawi jika di komparasikan reaksi indra hewan dan manusia, ternyata daya reaksi hidayah indera yang dimiliki hewan itu jauh lebih kuat dibandingkan dengan inderawi manusia, seba b inderawi hewan sudah berada pada tingkat kesempurnaanketika hewan itu dilahirkan. Sedangkan manusia perkembangan menuju kematangannya berjalan secara bertahapdari titik start yang jauh dari titik kematangan dan memakan waktu yang relatif panjang.

3. Hidayah akal. Diantara ciri keberadaan manusia sebagai makhluk Tuhan adalah identitasnya sebagai makhluk sosial. Manusia tidak mungkin hidup sempurna tanpa keberadaan sebuah komunitas sosial. Bagi muhammad abduh fungsi akal bagi manusia selain sebagai pembeda dari makhluk lainnya. Sekaligus juga menjadi faktor keistimewaan dan keunggulan atas ciptaan Tuhan lainnya. Keistimewaan akal terletak dari fungsinya sebagai alat untuk pembenar inderawi dalam mengukur kebenaran yang sesungguhnya. Juga akal sebagai filter atas kesalahan dan kekeliruan alat inderawi dalam mengukur kebaikan, kebenaran dan kesesatan.

4. Hidayah agama. Menurut Abduh agama merupakan bentuk hidayah, karena dengan dengan hidayah akal saja tidak mencukupi, bahkan seringkali dengan akal tersebut akan menggelincirkan manusia kepada kesesatan. Hal ini disebabkan karena akal seringkali tunduk kepada syahwat dan keinginan hewani, dengan demikian agama menjadi sebuah kebuTuhan yang dijadikan pembimbing kepada jalan kebenaran.

5. Hidayah Ma'unah. Hidayah maunah ini dapat di simpulkan dari firman Allah SWT dalam surah al-Anam ayat 90:

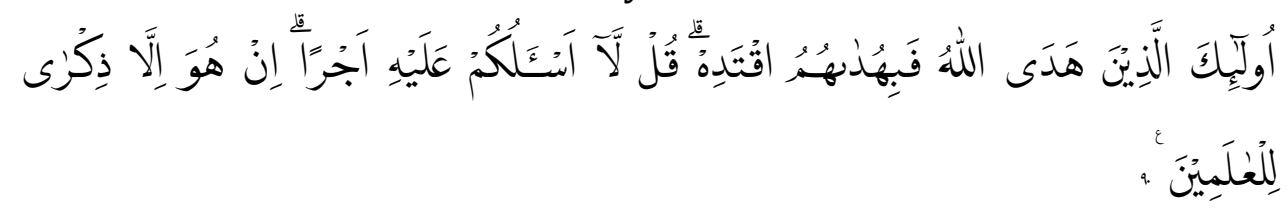

Mereka itulah (para nabi) yang telah diberi petunjuk oleh Allah, maka ikutilah petunjuk mereka. Katakanlah (Muhammad), "Aku tidak 
meminta imbalan kepadamu dalam menyampaikan (Al-Qur'an).” AlQur'an itu tidak lain hanyalah peringatan untuk (segala umat) seluruh alam.

Hidayah dalam hal ini lebih spesifik dari semua hidayah, yaitu menolong dan membimbing manusia agar menempuh jalan yang baik dan selamat. Hidayah yang seperti ini tidak bersifat general laiknya hidayah akal, inderewi dan agama.

Ahmad mustafha al-maraghi mufassir kontemporer dari mesir, membagi hidayat pemberian Allah SWT kepada manusia menjadi dua bentuk yaitu : al-hidyah al-ammah ( Hidayah umum) dan Hidayah al-Khas (Hidayah Khusus) hidayah yang umum dapat diberikan Allah kepada segenap manusia untuk dijadikan sebagai petunjuk dalam hidupnya. Sedangkan hidayah khusu hanya dianugrahkan Allah SWT kepada sebagian manusia saja.

Hidayah Umum oleh al-maraghi dibagi lagi kepada empat bentuk:

1. Hidayah ilham . (petunjuk Ilham) yaitu erupa gharizah (insting), pembawaan asli) yang di bawa asli oleh setiap manusia sejak lahir. Hidayah ini diumpamakan kepada bayi yang baru lahir yang tanpa belajar dapat menyusu pada ibunya.

2. Hidayah al-hawaas (Inderawi) yaitu berupa pendengaran, penglihatan, penciuman, perasaan, dan pearabaan. Dngan hidayah Inderawi manusia dapat membedakan suatu yang bermamfaat dan mudarat, akan tetapi belum dapat menghantarkan manusia kepada kebenaran, karena alat indra peuh keterbatasan.

3. Hidayah al-Aql (Petunjuk akal), yaitu berupa kemampuan akal untuk memikirkan, memahami, dan mengetahui suatu objek yang akan membawanya kepada kebenaran dan keselamatan hidup. Al-Qur'an menganjurkan manusia untuk memperhatikan, memikirkan, memahami lingkungan sekitarnya. Ini terlihat pada surah Ali Imran ayat 190:

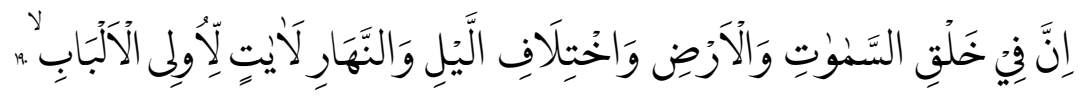

Sesungguhnya dalam penciptaan langit dan bumi, dan pergantian malam dan siang terdapat tanda-tanda (kebesaran Allah) bagi orang yang berakal,

4. Hidayah agama dan syari'at . Hidayah ini mutlak diperlukan oleh mereka yang akalnya tidak mampu melepas diri dari perbudakan hawa nafsu.

5. Hidayah Ma'unah dan Taufiq yang secara aktual menyampaikan atau menghantar seseorang ke tujuan yang hakiki dengan mendapat 
bimbingan kemudahan dari Allah $\mathrm{SWT}^{\wedge}$ untuk mencari yang haq dan disingkirkan hambatan menuju kepadanya (al-Maraghi, 2001, hlm. 154).

Berbagai jenis dan tingkatan hidayah sebagaimana yang dikemukakan oleh para ulama diatas mengambarkan sumber hidayah. Substansi hidayah, sifat hidayah dan butuh makhluk Tuhan kepada namanya hidayah.

Sementara proses untuk memperoleh hidayah tidak begitu tergambar dengan jelas sehingga peran manusia dalam memperoleh hidayah belum terungkap. Pengungkapan ada tidaknya peran manusia dalam memperoleh hidayahitu tidak terlihat dalam pendangan ulama mengenai hak terhadap hidayah. Setidakny ada dua pandangan ulam' berkenan dengan hal ini. Pandangan pertama menyatakan bahwa hidayah merupakan hak mutlak Allah Swt. Pandangan ini antara lain disampaikan oleh al-Wahidi. Pandangan kedua menyatakan bahwa hidayah merupakan iklhtiar manusia. Pendapat ini dikemukakan oleh al-Baidhawi. Dia membantah pendapat yang menyatakan bahwa orang yang mendapat kesesatan itu dan tepatnya kesesatan itu disebabkan oleh perbuatan Tuhan dan keinginannya. Pernyataan ini secara ekdplisit menunjukkan bahwa hidayah bukan semata hak Tuhan, akan tetapi menjadi suatu yang harus diusahakan oleh manusia (Baidhawi, t.t., hlm. 397).

\section{Hubungan hidayah dengan perbuatan manusia.}

Hubungan hidayah dan perbuatan manusia tidak lah bertentangan dengan adanya kaitan kata hidayah dengan sebagaimana dalam surat alHujurat ayat 17:

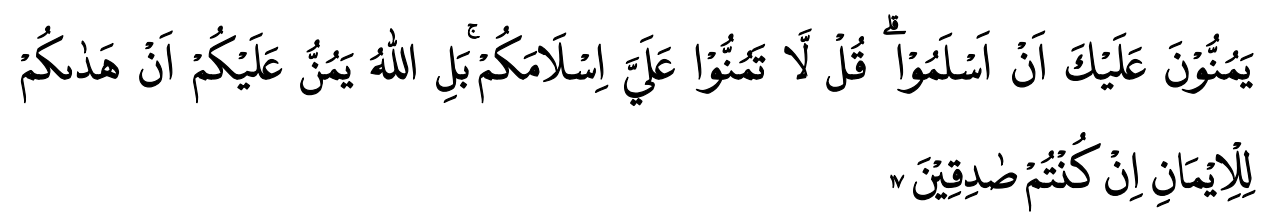

Mereka merasa berjasa kepadamu dengan keislaman mereka. Katakanlah, "Janganlah kamu merasa berjasa kepadaku dengan keislamanmu, sebenarnya Allah yang melimpahkan nikmat kepadamu dengan menunjukkan kamu kepada keimanan, jika kamu orang yang benar."

Pada ayat ini menunjukkan bahwa iman itu adalah hasil dari hidayah Tuhan. Dan hidayah Tuhan di tangkap melalui proses yang rasional bukan dalam arti menjadikan iman didalam hati manusia oleh karena itu kalimat “ In hadakum lil iman" ditafsirkan dengan " Allah telah mempasilitasi kamu untuk beriman" ayat ini turun berkenaan dengan Bani Asad yang mengharap balasan keislaman dari Rasullah, karena mereka masuk Islam tanpa melalui 
peperangan. Maka Rasulullah diperintahkan untuk menjawab “ jangan lah kamu mengharapkan balasan keislaman dariku, tetapi Allah telah memberi kamu nikmat dengan menunjuki kamu kepada Iman".

Tafsiran ayat ini sejalan dengan tafsiran yang disampaikan oleh alBaidhawi. Menurut al-Bhaidawi bahwa hidayah dalam ayat diatas adalah bukan dalam arti menjadikan orang untuk beriman, dalam bahasa yang dikemukakannya, " bahwa tidak mesti adanya hidayah itu orang mendapat petunjuk".

Hubungan hidayah dan perbuatan hamba dapat dilihat pula pada penggunaan kata hidayah yang di isnadkan kepada Allah SWT. Tela'ah terhadap penggunaan kata hidayah yang di isnadkan kepada Allah menunjukkan bahwa tidak ada kata hidayah yang digunakan dalam arti menjadikan iman dalam kalbu manusia. Keseluruhan ayat hidayah yang diisnadkan kepada Tuhan menunjukkan bahwa hidayah adalah suatu proses yang harus dijalani oleh manusia kecuali hidayah yang diberikan para Nabi dan rosul. Demikian pula dengan kesesatan. Karena hidayah merupakan suatu peroses tidak bertentangan dengan firman Allah. Tafsiran al-Baqarah ayat 7 adalah Allah telah mengunci rapat hati yang kafir. Maka kekufuranlah yang sesungguhnya menjadi penyebab Tuhan mengunci hati mereka sehingga mereka tidak dapat petunjuk, Mujahid menafsirkan bahwa hati bagaikan telapak tangan. Apabila seorang hamba melakukan dosa maka tergenggam suatu jari dan mana kala dosa itu sampai pada tahap kekufuran, maka tertutup rapat hatinya bagaikan telapak tangan jarinya yang tertutup rapat. Dengan demikian penguncian hati oleh Allah kepada orang-orang kafir disebabkan oleh dosa mereka sendiri. Hal ini juga disampaikan oleh alZamakhsari kata al-Khotmu adalah sebagai kiasan saja. Karena tidak ada penguncian dan penutupan terhadap hati manusia oleh Tuhan. Artinya kebenaran tidak bisa menembus hati mereka. Penguncian dan penutupan hati mereka oleh Tuhan karena mereka berpaling dari ajakan rosul, memandang remeh ajaran Tuhan(Al-Zamakhsyari, t.t., hlm. 155).

Al-Baidhawi mempunyai tafsiran yang sama dengan tafsiran yang dikemukakan oleh al-Zamakhsyari. Menurut al-Baidhawi penguncian hati mereka itu tidak lain adalah sebagai akibat dari kesesatan mereka sendiri sehingga kebenaran tidak dapat menembus hati mereka (Baidhawi, t.t., hlm. 70).

Menurut Rasyid ridha bahwa pengisnadan penguncian hati dan pendengaran orang kafir kepada Tuhan merupakan penjelasan sunnatullah terhadap orang yang sama dengan mereka. Dan hal itu tidak berarti bahwa 
mereka dipaksa menjadi kafir dan tidak pula berarti bahwa Allah mengcegah mereka menjadi kafir (Rasiyd Ridho, t.t., hlm. 143) .

Kemudian tafsiran terhadap surah an-nisa ayat 155 memberikan kesimpulan yang sama dengan tafsiran al-Baqarah ayat 7. Al-Baidhawi menafsirkan penggalan ayat "bal Thaba'a Allahu 'alaiha" dengan " maka Allah jadikan hati-hati mereka terhijabdari mendapatkan atau dibiarkan tanpa pertolongan Tuhan, atau dicegah untuk mendapat taufiq sehingga tidak dapat memahami ayat-ayat Tuhan dan menangkap pelajaran. Lebih lanjut alBaidhawi menafsirkan "Bikufrihim" dengan faktor penyebab penguncian hati (Baidhawi, t.t., hlm. 127).

Tafsir al-Baidhawi ini memberi kesan bahwa penguncian hati mereka sebab kekufuran mereka sendiri. al- Zamakhsyari memandang bahwa penggalan ayat " Bal-Thaba'a Allahhu 'Alaiha bikufrihim" sebagai bantahan dan pengingkaran terhadap ucapan mereka yang mengatakan bahwa hati kami diciptakan tertutup sehingga tak terjamah peringatan dan pelajaran. Tetapi hati itu dibiarkan oleh Allah tanpa pertolongan dan tercegah untuk memperoleh taufik disebabkkan kekafiran mereka sehingga jadilah hati itu seperti barang yang tertutup (Al-Zamakhsyari, t.t., hlm. 578). Tafsiran yang dikemukakan oleh Zamakhsyari ini mendekati kepada tafsiran yang dikemukakan oleh al-Baidhawi diatas. Secar lebih tegas Ibn Kastir mengatakan " ini adalah di antara dosa-dosa yang telah mereka lakukan yang mengakibatkan mereka dilaknat dan jauh dari hidayah” (Al-Zamakhsyari, t.t., hlm. 578) .

Rasyid ridha juga mempunyai tafsiran yang sama yaitu bahwa penguncian hati mereka disebabkan karena kekufuran dan maksiat (Rasiyd Ridho, t.t., hlm. 143).

Hubungan Hidayah dengan perbuatan hamba dapat juga dilihat dari penggunaan kata " Mudhill" dalam al-Qur'an. Kata "Mudhill” terulang sebanyak 3 kali dalam al-Qur'an, 2 kali dalam bentuk mufrad dan satu kali dalam bentuk jamak. Tidak satupun di antara 3 itu yang di isnadkan kepada Allah. Ketiga ayat itu terletak pada suarah al-Qashas ayat 15, surat al-Zumar ayat 37, dan surah al-Kahfi ayat 51.

Pada surah al-Qashas ayat 15, kata "mudhil' kembali kepada Syaithan. Pada surah al-Zumar ayat 37 kembali kepada makhluk selain Allah dan pada surah al-Kahfi ayat 52 kembali kepada makhluk Allah yang jauh dari petunjuk. Kenyataan ini menunjukkan bahwa kesesatan yang menimpa hamba bukan karena Allah tetapi oleh perbuatan hambanya sendiri. kalaupun kemudian terdapat ayat-ayat yang secara harfiah memberikan kesan bahwa Allah jualah yang menyesatkan, maka ayat-ayat seperti ini 
harus difahami dalam kontek sebab akibat atau Tuhan dalam posisi penyampai informasi yang baik dan buruk. Dan ini sejalan pula dengan makna hadis nabi yang berbunyi. :

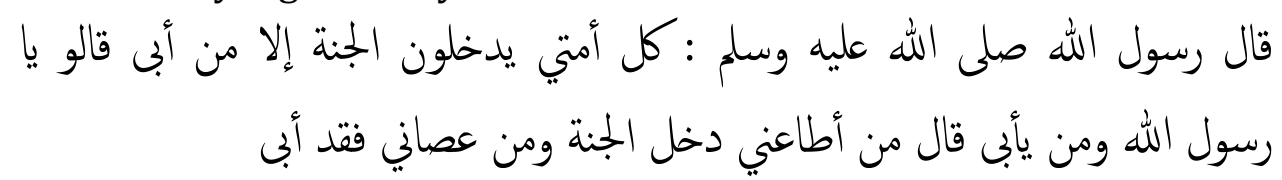

Rasulullah bersabda; " seluruh umatku akan masuk syurga, kecuali mereka yang enggan" (para sahabat bertanya): "siapa yang enggan itu ya Rasulullah? Nabi menjawab: Barang siapa taat kepadaku pasti msuk syurg dan barangsiapa yang durhaka terhadapku, mereka itulah orang yang enggan (Abu Abdullah Al-Bukhari, t.t., hlm. 2655).

\section{Faktor yang mendorong penerimaan Hidayah}

Faktor faktor yang melapangkan penerimaan hidayah dan faktorfaktor penghalang penerimaan hidayah serta isnad-an kata hidayah kepada Allah, dan pemakai kata "mudhil" dalam al-Qur'an merupakan bukti dan dasar argumentasi yang cukup kuat untuk menyatakan bahwa untuk mendapatkan dan memperoleh hidayah Allah SWT membutuhkan peran aktif manusia.

Peran aktif manusia untuk mendapatkannya dimulai Azam manusia itu sendiri. selama manusia memainkan peran aktifnya, maka ia akan mendapatkan hidayah. Dengan kata lain bahwa perolehan hidayah terkait dengan perbuatan hamba. Lebih jauh lagi dapat dinyatakan bahwa hidayah merupakan sebuah proses yang menuntun hamba-hamba Tuhan untuk terus menerus mencarinya dalam rangka kesempurnaan kehidupannya di dunia dan di akhirat. Selain itu pemaparan tersebut juga memberikan sebuah isyarat bahwa ada syarat-syarat tertentu yang harus dipenuhi oleh seorang hamba dalam rangka untuk mendapatkan hidayah Tuhan, terutama hidayah ma'unah.

Proses pencapaian hidayah ini terlihat pada keislaman Umar Ibn alKhattab yang bersipat dadakan dan spontanitas, tetapi ia melalui tahapantahapan yang memakan waktu (Ibn Ayyub al-Humairi, t.t., hlm. 187),

Proses yang sama juga dialami oleh Margaret Marcus dari keluarga Yahudi yang mengalami kegelisahan spritual dan mencoba mencari kebenaran melalui pusat-pusat kerohanian, dari yang bersifat keagamaan hingga yang bersifat agnostig, bahkan ateistik sekalipun. Upaya ini ternyata tidak juga mencapai kepuasan yang ia inginkan, berbagai buku filosofi dari berbagai aliran, buku-buku psikologi, dan berbagai buku keagamaan dipelajarinya secara seksama, dan pada akhirnya ia memutuskan pilihannya 
pada agama Islam sejak setelah mengucapkan kalimah syahadat ia pun berganti nama menjadi Maryam Jamilah (Fathul Umam, 1989, hlm. 5).

\section{Faktor-faktor yang penghambat penerimaan hidayah}

Proses untuk mendapat hidayah tampaknya sangat tergantung dengan faktor Internal dn eksternal. Faktor internal itu yang berasal dari pribadi orang yang bersangkutan sedangka faktor eksternal adalah suatu yang berada di luar pribadi penerima hidayah yang wujudnya berupa rasul, al-Qur'an dan lain-lain. Faktor pertama yang sangat menentukan bagi penerima hidayah itu adalah adanya 'azam atau keinginan keras dari penerima hidayah. Ini di tunjukkan oleh surt al-Nahl ayat 37 dan surah alQashas ayat 56:

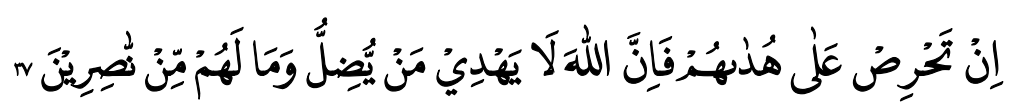

Jika engkau (Muhammad) sangat mengharapkan agar mereka mendapat petunjuk, maka sesungguhnya Allah tidak akan memberi petunjuk kepada orang yang disesatkan-Nya, dan mereka tidak mempunyai penolong.

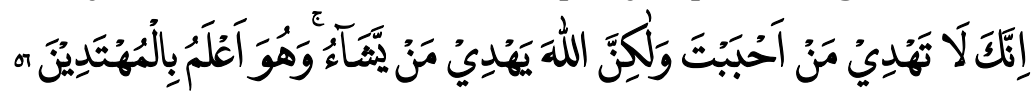

Sungguh, engkau (Muhammad) tidak dapat memberi petunjuk kepada orang yang engkau kasihi, tetapi Allah memberi petunjuk kepada orang yang Dia kehendaki, dan Dia lebih mengetahui orang-orang yang mau menerima petunjuk.

Faktor kedua adalah ittiba'i rasul atau mengikuti rosul sebagaimana yang dikemukan pada surat an-Nur ayat 54:

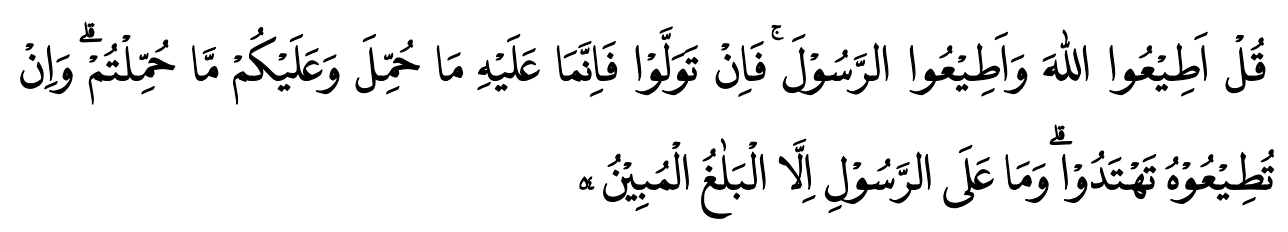

Katakanlah, "Taatlah kepada Allah dan taatlah kepada Rasul; jika kamu berpaling, maka sesungguhnya kewajiban Rasul (Muhammad) itu hanyalah apa yang dibebankan kepadanya, dan kewajiban kamu hanyalah apa yang dibebankan kepadamu. Jika kamu taat kepadanya, niscaya kamu mendapat petunjuk. Kewajiban Rasul hanyalah menyampaikan (amanat Allah) dengan jelas."

Dalam ayat ini Allah SWT memerintakan kepada Rasullulah untuk menyampaikan kepada orang munafik agar mentaati Allah dan rasul. Manakala mereka mentaati Rasul maka mereka akan mendapatkan petunjuk. Ayat ini berkaitan pula dengan dengan surah an-Nur ayat 52: 


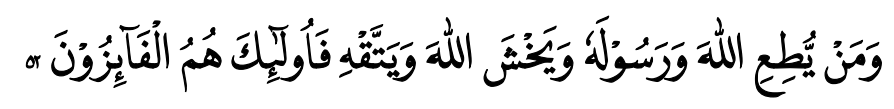

Dan barangsiapa taat kepada Allah dan Rasul-Nya serta takut kepada Allah dan bertakwa kepada-Nya, mereka itulah orang-orang yang mendapat kemenangan.

Allah SWT menjelaskan bahwa orang yang taat kepada Allah dan rasulnya kemudian takut serta takwa kepadanya maka mereka akan mendapat keuntungan.

Faktor ketiga adalah iman, sebagaimana dikemukakan dalam surah alBaqarah ayat 137:

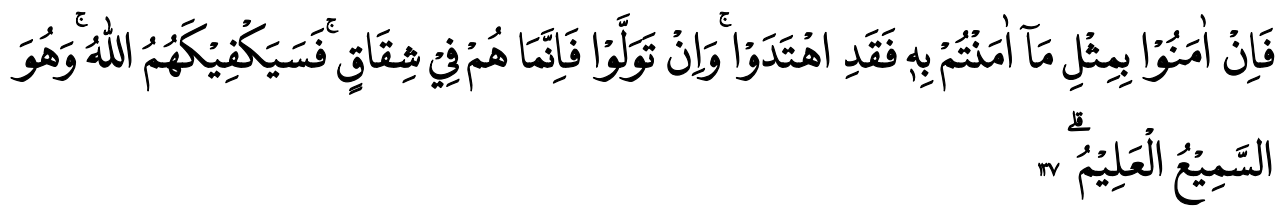

Maka jika mereka telah beriman sebagaimana yang kamu imani, sungguh, mereka telah mendapat petunjuk. Tetapi jika mereka berpaling, sesungguhnya mereka berada dalam permusuhan (denganmu), maka Allah mencukupkan engkau (Muhammad) terhadap mereka (dengan pertolonganNya). Dan Dia Maha Mendengar, Maha Mengetahui.

Ayat ini berkait dengan ayat sebelumnya, yaitu ayat 136:

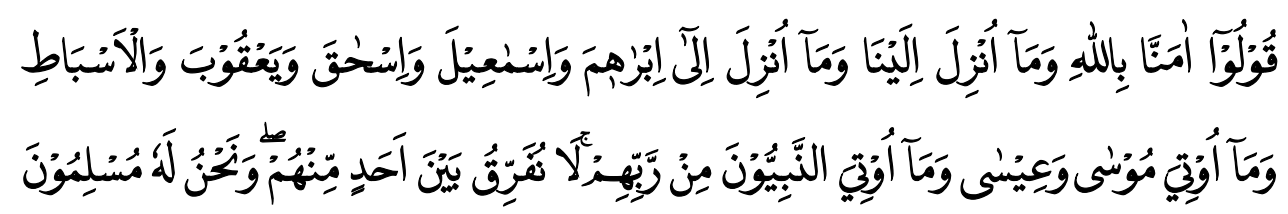

Katakanlah, "Kami beriman kepada Allah dan kepada apa yang diturunkan kepada kami, dan kepada apa yang diturunkan kepada Ibrahim, Ismail, Ishak, Yakub dan anak cucunya, dan kepada apa yang diberikan kepada Musa dan Isa serta kepada apa yang diberikan kepada nabi-nabi dari Tuhan mereka. Kami tidak membeda-bedakan seorang pun di antara mereka, dan kami berserah diri kepada-Nya."

Dalam ayat ini dijelaskan orang-orang beriman diperintahkan untuk mengatakan kepada ahli-kitab bahwa orang-orang beriman kepada Allah SWT dan mengimani pula kepada apa yang diturunkan kepada nabi-nabi sebelumnya dan mereka (orang mukmin) tidak membeda-bedakan antara para nabi itu. Kemudian di dalam surah al-Baqarah ayat 137 Allah SWT menegaskan apabila ahli kitab melakukan hal yang sama sebagaimana yang dilakukan oleh orang-orang yang beriman maka orang-orang ahli kitab akan 
mendapatkan petunjuk dalam menyelesaikan pertentangan yang terjadi di antara mereka. Ayat ini sejalan juga dengan firman Allah pada surah al-qarah ayat 5 yang menerangkan bahwa orang-orang yang bertaqwa itu mendapatkan petunjuk setelah mereka beriman. Bahkan al-Baidhawi mengibaratkan hidayah Allah adalah wujud agama. Bagaikan makanan yang bergizi tinggi, ia hanya akan bermamfaat bagi orang yang alat percernaan nya bekerja dengan baik. Jadi disini berlaku ketentuan yang bersifat objektif dalam proses pencapaian hidayah bagi manusia (al-Baidawi, 1996, hlm. 48).

Faktor keempat adalah mengikuti petunjuk kitab-kitab Allah SWT sebagaiman tergambar dalam surah al-Naml ayat 92 dan surah al-Zumar ayat 41:

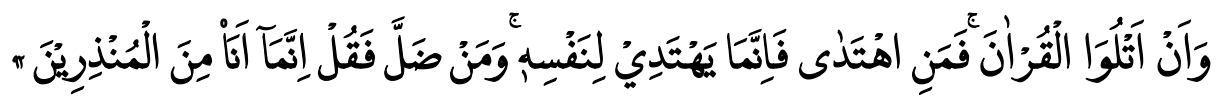

dan agar aku membacakan Al-Qur'an (kepada manusia). Maka barangsiapa mendapat petunjuk maka sesungguhnya dia mendapat petunjuk untuk (kebaikan) dirinya, dan barangsiapa sesat, maka katakanlah, "Sesungguhnya aku (ini) tidak lain hanyalah salah seorang pemberi peringatan."

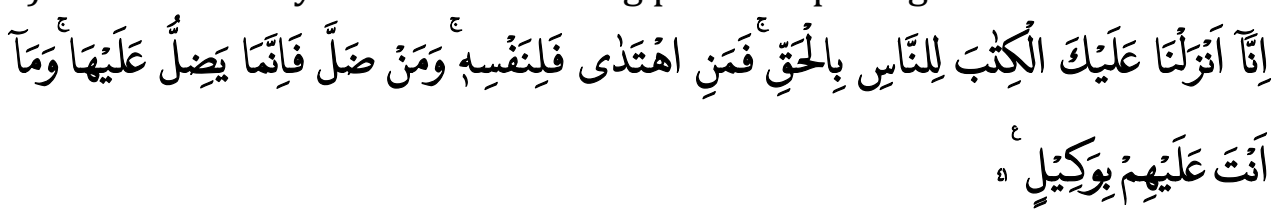

Sungguh, Kami menurunkan kepadamu Kitab (Al-Qur'an) dengan membawa kebenaran untuk manusia; barangsiapa mendapat petunjuk maka (petunjuk itu) untuk dirinya sendiri, dan siapa sesat maka sesungguhnya kesesatan itu untuk dirinya sendiri, dan engkau bukanlah orang yang bertanggung jawab terhadap mereka.

Dalam surah al-Naml ayat 92 ini Allah memerintah kepada rasulullah untuk membacakan al-Qur'an kepada umatnya agar supaya umatnya mendapatkan petunjuk. Dan pada surah al-Zumar ayat 41 menegaskan bahwa Allah SWT telah menurunkan al-kitab yang membawa kebenaran untuk ditaati manusia. Tujuannya adalah supaya manusia mendapatkan petunjuk. Dan bagi umat manusia yang tidak mau mengikuti kebenaran yang dibawa kitab suci itu maka bukan tanggung jawab rasul sebagai penyampai kitab suci tersebut. Ayat ini terkait dengan surat al-Zumar ayat 39-40 yang menjelaskan amal yang dianjurkan dan azam yang pedih agar manusia mengetahui mana amal yang dianjurkan dan mana amal yang membawa azab maka diturunkanlah kitab suci al-Qur'an.

Faktor yang kelima adalah tidak mencampur adukkan keimanan dan kezaliman, sebagaimana yang dikemukakan dalam surat al-An'am ayat 82 . Ibn Katsir mengemukakan mereka yang tidak mencampur adukkan 
keimanan dan kezaliman adalah mengikhlaskan diri untuk beribadah kepada Allah SWT semata dan tidak melakukan kemusyrikan. Mereka adalah orang yang beriman kepada hari kiamat dan mendapatkan petunjuk di dunia dan di akhirat (Ibnu Kastir, 1401, hlm. 153).

\section{Hubungan Hidayah dengan Hak Mutlak Allah}

Hubungan Hidayah dan Hak Mutlak Allah dapat di analisis dari wujud Hidayah. Telaah terhadap ayat-ayat Hidayah dan wujud hidayah ada beberapa macam :

\section{Wahyu}

Menurut Majd al-Din al-Fairuz dalam kamus al-Muhith, wahyu berarti isyarat, tulisan, risalah, ilham, perkataan yang tersembunyi.

Hidayah dalam bentuk ini dapat ditemukan dalam surat Saba' ayat $50^{1}$ dan surat al-'Araf ayat 203.

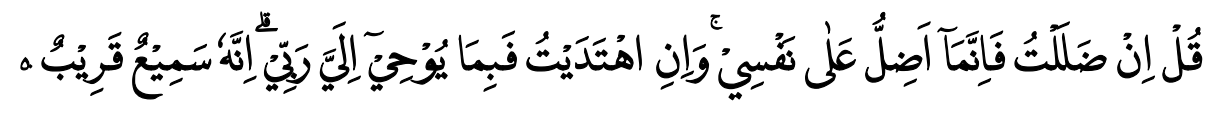

Katakanlah, "Jika aku sesat maka sesungguhnya aku sesat untuk diriku sendiri; dan jika aku mendapat petunjuk maka itu disebabkan apa yang diwahyukan Tuhanku kepadaku. Sungguh, Dia Maha Mendengar, Mahadekat."

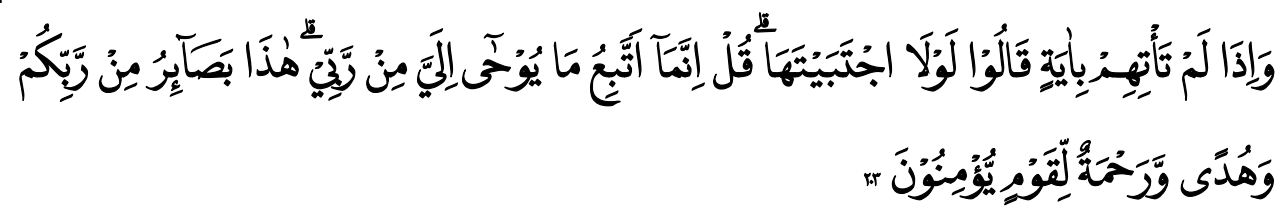

Dan apabila engkau (Muhammad) tidak membacakan suatu ayat kepada mereka, mereka berkata, "Mengapa tidak engkau buat sendiri ayat itu?" Katakanlah (Muhammad), "Sesungguhnya aku hanya mengikuti apa yang diwahyukan Tuhanku kepadaku. (Al-Qur'an) ini adalah bukti-bukti yang nyata dari Tuhanmu, petunjuk dan rahmat bagi orang-orang yang beriman.

Ayat pertama menurut al-Syaukani merupakan perintah Tuhan kepada Rasullah untuk merespon anggapan orang kafir bahwa apabila rasullAllah meninggalkan agama nenek moyangnya, RasulAllah akan menjadi sesat, itu disebabkan karena diri RasulAllah sendiri dan apabila ia mendapat hikmah, mau'izhah dan penjelasan al-Qur'an (Al-Syaukani, t.t., hlm. 335).

\section{Kitab suci}

Hidayah dalam bentuk kitab suci banyak ditemukan mengingat cakupan kitab suci meliputi semua kitab yang diturunkan oleh Allah SWt kepada nabinya. Antara lain seperti dalam surat al-Baqarah ayat 185: 


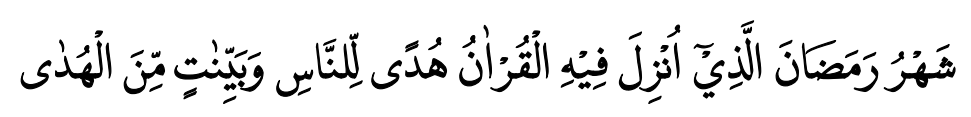

Bulan Ramadan adalah (bulan) yang di dalamnya diturunkan Al-Qur'an, sebagai petunjuk bagi manusia dan penjelasan-penjelasan mengenai petunjuk itu dan pembeda (antara yang benar dan yang batil)

Ayat diatas merupakan hidayah yang merujuk kepada al-Qur'an. Pada surat al-maidah ayat 44 yang merujuk kepada Taurat :

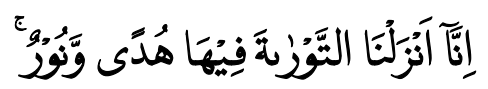

Sungguh, Kami yang menurunkan Kitab Taurat; di dalamnya (ada) petunjuk dan cahaya.

Dan juga terdapat dalam surah al-maidah ayat 46 yang merujuk kepada kitab injil :

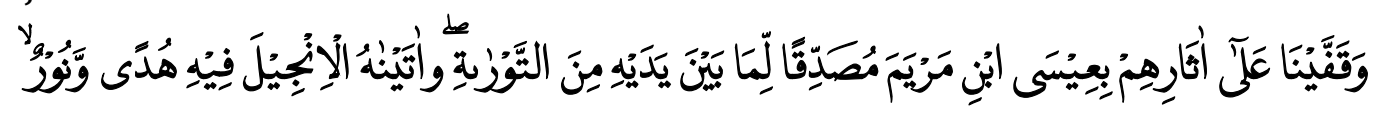

Dan Kami teruskan jejak mereka dengan mengutus Isa putra Maryam, membenarkan Kitab yang sebelumnya, yaitu Taurat. Dan Kami menurunkan Injil kepadanya, di dalamnya terdapat petunjuk dan cahaya,

Kata hudan yang berkaitan dengan kitab suci di atas ketika berkaitan dengan Taurat dan Injil sebagai wujud hidayah yang memiliki dimensi waktu yaitu berlaku sampai periode turunnya kitab berikutnya serta berlaku bagi kaumnya sendiri. sementara yang berkaitan dengan al-Qur'an tidak dibatasi oleh dimensi-dimensi tersebut. Karena al-Qur'an bersipat Universal.

\section{Syariat.}

Hidayah dalam bentuk syari'ah dibahasakan dengan mansaka yang memilki makna syari'ah. Hal ini ditemukan di dalam surah al-Hajj ayat 67 :

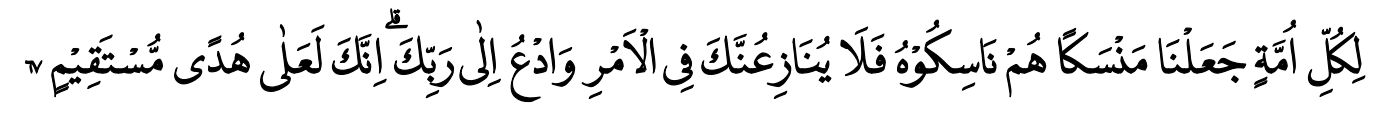

Bagi setiap umat telah Kami tetapkan syariat tertentu yang (harus) mereka amalkan, maka tidak sepantasnya mereka berbantahan dengan engkau dalam urusan (syariat) ini dan serulah (mereka) kepada Tuhanmu. Sungguh, engkau (Muhammad) berada di jalan yang lurus.

Al-Taba'i memahami Mansaka sebagai masdar dengan arti ibadah sesuai dengan redaksi sesudahnya yang bermakna mengamalkan ibadahibadah tersebut. Hidayah diartikan jalan yang lurus. (Thabathaba'i, 1379, hlm. 445). 


\section{Rasul}

Rasul diutus Oleh Allah untuk menyampaikan risalah kepada seluruh umat manusia. Dan rasul merupakan bagian dari wujud hidayah hal ini terdapat didalam firman Allah pada surat al-Isra' ayat 94 :

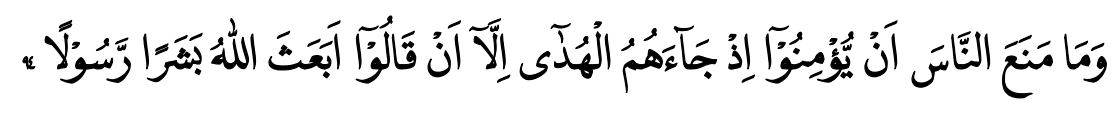

Dan tidak ada sesuatu yang menghalangi manusia untuk beriman ketika petunjuk datang kepadanya, selain perkataan mereka, "Mengapa Allah mengutus seorang manusia menjadi rasul?"

Al-Baidhawi memahami al-Huda dalam ayat ini dengan wahyu (alBaidawi, 1996, hlm. 467). Sedangkan Ibn Kastir memahami ayat ini pengutusan rasul (Ibnu Kastir, 1401) Hlm 68. Dan al-Thabari memahami ayat ini dengan rasul dan kitab. (al-Thabari, 1405, hlm. 166).

Pemaparan tentang wujud yang berupa wahyu, Kitab suci, Syari'at, dan Rasul menunjukkan adanya kehendak mutlak Tuhan dalam pemberian hidayah. Akan tetapi kehendak mutlak Tuhan tersebut adalah penyediaan media dan sarana yang telah diberikannya untuk mendapatkan hidayah. Adapun pemamfaatan media dan sarana tersebut terpulang kepada usaha hambanya sendiri. wujud hidayah berupa kitab suci dan rasul umpamanya tidak akan memberikan mamfaat dalam arti petunjuk bagi orang yang tidak membuka diri untuk menerimanya. Sebaliknya orang yang bersedia membuka diri akan memperoleh petunjuk yang mengantarkannya kepada keselamatan..

\section{PENUTUP}

Konsep al-Qur'an tentang hidayah yaitu sebagaimana yang terdapat dalam al-Qur'an menunjukkan bahwa hidayah itu disamping ketetapan tuhan ia juga sebagai sebuah peroses yang menuntut peran aktif manusia dalam mendapatkannya.

Hidayah sebagai sebuah ketetapan Tuhan telah berakhir dengan penciptaan alam, pengutusan rasul, dan penurunan kitab suci al-Quran. Sementara hidayah sebagai peroses belum berakhir. Hidayah dalam pengertian ini masih menuntut perjuangan keras dari setiap orang untuk mendapatkannya, hidayah dalam pengertian ini sangat mempengaruhi kualitas keberagamaan seseorang. Selama manusia itu masih mencarinya, maka selama itu pula ia memungkinkan untuk menerima atau mendapat hidayah.

Proses untuk mendapat hidayah tampaknya sangat tergantung dengan faktor Internal dn eksternal. Faktor internal itu yang berasal dari pribadi orang yang bersangkutan sedangkan faktor eksternal adalah suatu 


\section{AT-TIBYAN}

Journal Of Qur'an and Hadis Studies

Volume. 2 No. 1 (Juni 2019)

yang berada di luar pribadi penerima hidayah yang wujudnya berupa rasul, al-Qur'an dan lain-lain.

\section{REFERENSI}

Abu Abdullah Al-Bukhari, M. I. I. (t.t.). Sahih Al-Bukhari: Vol. VI. Dar al-Fikr. al-Fansuri, Abd. A.-R. ibn A. (t.t.). Tarjuman al-Mustafid.

al-Maraghi, A. M. (2001). Tafsir al-Maraghi. Dar al-Fikr.

al-Thabari, M. I. J. I. Y. I. K., Abu Ja'far. (1405). Jami' al-Bayan an-Ta'wil Ayi alQur'an. Dar al-Fikr.

al-Baidawi. (1996). Tafsir al-Baidawi: Vol.juz 1. Dar al-Fikr.

Al-Syaukani, M. ibn ali ibn M. (t.t.). Fath al-Qadir al-Jami' Baina Fannai alRiwayah wa al-Dirayah Min Ilm Tafsir. Dar al-Fikr.

Al-Zamakhsyari. (t.t.). Al-Kasysyaf. Dar al-Fikr.

Baidhawi. (t.t.). Al-Anwar at-Tanzil wa Asrar al-Ta'wil (Tafsir al-Baidhawi) (II). Dar- Shadir,.

Fathul Umam. (1989). Anonim, Correspodence between Maulana and Maryam jamilah, (Surat menyurat Maryam Jamilah al-Maududi. Mizan.

ibn Asyir, T. (t.t.). Al-Tanwir wa al-Tanzih.

Ibn Ayyub al-Humairi, A. al-muluk I. H. (t.t.). Al-Sirah al-Nabawiyah (Vol. 1). Ibnu Kastir. (1401). Tafsir Ibn Katsir: Vol. I. Dar al-Fikr.

Ma'luf, L. (1986). Al-Munjid fi al-Lughah. maktabah al-Syarqiyyah.

Rasiyd Ridho, R. (t.t.). Tafsir al-Manar: Vol. Juz 1. Dar-alFikri.

Ridwan, K., \& dkk. (2001). Enseklopedi Islam. Ikrar Mandiri Abadi.

Sabiq, S. (1992). Al-Aqaid al-Islamiyyah. Dar-alFikri.

Salim, P., \& Salim, Y. (1991). Kamus Bahasa Indonesia Kontemporer. Modern English Press.

Thabathaba'i, sayyid muhammad ibn H. (1379). Al-mizan fi al-tafsir al-Qur'an al-Karim. Dar- al-kutub al-Islamiyah. 